Stanisław Nitecki*

\title{
WSPÓLNA OBSŁUGA JEDNOSTEK \\ ORGANIZACYJNYCH SAMORZAZDU \\ TERYTORIALNEGO JAKO PRZEJAW \\ CENTRALIZACJI CZY KONCENTRACJI
}

1.

Jednostki samorządu terytorialnego dysponują samodzielnością ${ }^{1}$ podlegającą ochronie sądowej. Rozwiązanie takie ma swoje zakotwiczenie w postanowieniach art. 165 ust. 2 Konstytucji RP. Sygnalizowana samodzielność musi być wiązana $\mathrm{z}$ realizacją powierzonych samorządowi terytorialnemu zadań oraz z możliwościami w zakresie samodzielnego kształtowania struktury podmiotów, przy wykorzystaniu których będzie te zadania wykonywał. Samodzielność ta wyznaczana jest normami ustawowymi, które określają, jakie rozwiązania może ona przyjąć. Wynika to z tego, że samorząd terytorialny jako część administracji publicznej może funkcjonować jedynie w ramach wyznaczonych przepisami prawa powszechnie obowiązującego. Poczynione uwagi wynikają z tego, że ustawodawca mocą ustawy z 25.06.2015 r. o zmianie ustawy o samorządzie gminnym oraz niektórych innych ustaw ${ }^{2}$ wpro-

* Stanisław Nitecki - doktor habilitowany nauk prawnych, profesor UO, Zakład Prawa i Postępowania Administracyjnego, Uniwersytet Opolski.

${ }^{1} \mathrm{Na}$ temat samodzielności jednostek samorządu terytorialnego zob. I. Lipowicz, Samodzielność samorządu terytorialnego w świetle konstytucji, „Przegląd Sejmowy” 2007/4, s. 175 i n.

${ }^{2}$ Dz.U. poz. 1045 ze zm. 
wadził w sposób powszechny możliwość powoływania przez jednostki samorządu terytorialnego wspólnej obsługi. Rozwiązanie takie zostało rozbudowane o regulacje zamieszczone w ustawie z 29.01.2004 r. o zamówieniach publicznych ${ }^{3}$, które rozszerzyły zakres przedmiotowy zadań wykonywanych przez tego typu jednostki. Przyjdzie dostrzec, że rozwiązanie takie było już wcześniej możliwe i dopuszczalne na gruncie unormowań zaliczanych do szeroko rozumianej pomocy społecznej ${ }^{4}$. Wprowadzenie do porządku prawnego wskazanego rozwiązania skłania do zwrócenia uwagi na jego charakter. Następstwem skorzystania przez jednostkę samorządu terytorialnego $\mathrm{z}$ tego rozwiązania jest powołanie w niej nowego podmiotu, który jest wyposażony do wykonywania przypisanych mu zadań. Charakter prawny i miejsce tego nowego podmiotu funkcjonującego w ramach struktur samorządu terytorialnego wymaga analizy, która przeprowadzona będzie z perspektywy pojęć centralizacji i decentralizacji zadań i struktur organizacyjnych administracji publicznej. Inaczej mówiąc, w ramach niniejszego opracowania przysługująca jednostkom samorządu terytorialnego możliwość powoływania podmiotów prowadzących wspólną obsługę rozpoznana będzie w kontekście kluczowych dla prawa administracyjnego pojęć, takich jak centralizacja i decentralizacja.

2.

W nauce administracji i prawa administracyjnego spotykamy się z sytuacjami, gdy pojęcia wykorzystywane do opisania określonych zjawisk społecznych są różnie ujmowane. Przykładem takiej sytuacji są różne rozumienia pojęć centralizacji i decentralizacji oraz koncen-

${ }^{3}$ Dz.U. z 2018 r. poz. 1986 ze zm.

${ }^{4}$ Na temat pojęcia pomocy społecznej zob. S. Nitecki, Prawo do pomocy społecznej w polskim systemie prawnym, Warszawa 2008, s. 29 i n. Rozwiązanie polegające na możliwości wspólnej obsługi przewidziane jest w art. 111a ustawy z 12.03.2004 r. o pomocy społecznej (Dz.U. z 2018 r. poz. 1508 ze zm.) oraz w art. 93 i 94 ustawy z 9.06.2011 r. o wspieraniu rodziny i systemie pieczy zastępczej (Dz.U. z 2018 r. poz. 998 ze zm.). Na marginesie należy zaznaczyć, że w przypadku placówek opiekuńczo-wychowawczych taka możliwość istniała wcześniej, zob. art. 94 w wersji nadanej ustawą z 25.07.2014 r. o zmianie ustawy o wspieraniu rodzin i systemie pieczy zastępczej oraz niektórych innych ustaw (Dz.U. poz. 1188). 
tracji i dekoncentracji. Przy tym występują także zjawiska, gdy jedni autorzy przez pojęcie centralizacji rozumieją koncentrację i odwrot$n^{2} e^{5}$. Zatem brak jest jednolitego ich rozumienia. Sytuacja taka rodzi negatywne konsekwencje, ponieważ dostrzegany jest chaos terminologiczny, powodujący liczne niezrozumienia i nieporozumienia.

Na wstępie niniejszych rozważań rozważenia wymaga problematyka dotycząca pojęć koncentracji i dekoncentracji. W ramach tego opracowania pojęcie koncentracji oznacza skupienie prawa do podejmowania decyzji w określonych dziedzinach w ręku jednego organu zajmującego wysoką pozycję w strukturze organów administracji ${ }^{6}$. Natomiast pojęcie dekoncentracji oznacza rozłożenie uprawnień decyzyjnych dotyczących pewnej dziedziny działalności administracji, a skupionych uprzednio w ręku jednego organu na większą liczbę tych organów administracyjnych (większą liczbę podmiotów mogących podejmować decyzje czy działania) ${ }^{7}$. W ramach dekoncentracji przeniesienie kompetencji następuje na organ zajmujący niższą pozycję w strukturze organizacyjnej lub też na organ równorzędny ${ }^{8}$. Wskazane pojęcia mogą być wykorzystywane do określenia układów wewnętrznych w ramach organów lub innych podmiotów administracji publicznej. W takim przypadku nie chodzi o wykonywanie kompetencji, lecz tylko o prosty, techniczny podział czynności między określoną liczbą podmiotów ${ }^{9}$. Prowadząc rozważania na temat dekoncentracji, uwagę należy zwrócić na jej istotne elementy. W pierwszej kolejności zauważyć należy, że jest dokonywana aktem wewnętrznym, czyli aktem organu dekoncentrującego uprawnienia. Przykładem takiego aktu jest upoważnienie osoby zatrudnionej w aparacie pomocniczym organu do podejmowania decyzji

${ }^{5} \mathrm{Na}$ wskazane zjawisko uwagę zwracali m.in. R. Buckley, R. Maurer, Decentralizacja $w$ Polsce: tworzenie potencjału racjonalnego zarzadzania $i$ integracji $z$ Unia Europejska, ST 2000/7-8, s. 3 i n.

${ }^{6}$ Zob. J. Lang, J. Służewski, M. Wierzbowski, A. Wiktorowska, Polskie prawo administracyjne, Warszawa 1995, s. 37.

7 E. Ura, Prawo administracyjne, Warszawa 1999, s. 35.

8 J. Boć [w:] Administracja publiczna, red. J. Boć, Wrocław 2003, s. 181; J. Izdebski [w:] Leksykon administratywisty, red. S. Wrzosek, A. Haładyj, M. Domagała, Radom 2013, s. 146.

9 J. Zimmermann, Prawo administracyjne, Warszawa 2014, s. 179. 
administracyjnych czy dokonywania innych czynności prawnych. W tego typu przypadkach ważne jest, aby stosowny dokument znajdował się w teczce personalnej osoby nabywającej takie uprawnienia. Przedstawiony element dekoncentracji oznacza, że organ dekoncentrujący uprawnienia może w każdym momencie przejąć $\mathrm{z}$ powrotem przekazane uprawnienia. Rozwiązanie takie oznacza, że przekazanie tych uprawnień nie jest równoznaczne $\mathrm{z}$ wyzbyciem się posiadanego prawa. Organ dekoncentrujący nie jest w sposób bezwzględny związany swoją decyzją, ponieważ w każdej chwili może dokonać jej zmiany, co oznacza, że udzielone upoważnienie do wydawania decyzji może być w pewnym momencie cofnięte ${ }^{10}$. Prezentowany proces udzielania upoważnień i jego cofania może odbywać się wielokrotnie, gdyż zależny jest wyłącznie od stanowiska piastuna uprawnień. W konsekwencji uznać należy, że przekazanie kompetencji jest wyrazem woli organu przekazującego (piastuna organu). Takie rozwiązanie oznacza, iż podmiot przejmujący nie może domagać się przekazania mu tych uprawnień, jednakże podmiot ten musi wyrazić zgodę na ich przejęcie. Zgoda ta może mieć różne przejawy, ale musi istnieć, ponieważ jeżeli osoba taka odmówi przyjęcia do realizacji przekazywanego zadania, wówczas musi liczyć się z możliwością zastosowania wobec niej negatywnych konsekwencji. W świetle powyższych rozważań uznać należy, że organ (podmiot) przejmujący przekazane kompetencje jest najczęściej organem (podmiotem) podporządkowanym organowi (podmiotowi) przekazującemu, zatem wówczas przekazanie kompetencji odbywa się w ramach struktury organizacyjnej danej administracji czy urzędu.

3.

Po przedstawieniu pojęć koncentracji i dekoncentracji kolej teraz na analizę drugiej pary wyodrębnionych pojęć, a mianowicie centralizacji i decentralizacji. W przypadku pojęcia centralizacji w literaturze przedmiotu wskazuje się na dwa znaczenia, w jakich ono występuje. Pierwsze $\mathrm{z}$ nich związane jest $\mathrm{z}$ budową struktury organizacyjnej ad-

${ }^{10}$ J. Boć [w:] Administracja..., red. A. Boć, s. 182-183. 
ministracji, która składa się z kilku stopni organizacji, ale rozstrzygnięcia podejmuje jedynie organ zajmujący pozycję najwyższą (organ centralny), natomiast drugie rozumienie tego pojęcia odnosi się do takich układów wewnętrznych administracji, które funkcjonują współcześnie. Występowanie wysoce zhierarchizowanych struktur jest uzasadnione celami, jakie realizują, ponieważ umożliwiają one sprawność kierowania, a czasami efektywność ${ }^{11}$.

Problematykę centralizacji i decentralizacji można rozpatrywać $\mathrm{w}$ ujęciu dynamicznym lub statycznym. Ujęcie dynamiczne polega na wskazaniu, czy mamy do czynienia z procesem centralizacji, czy też z procesem decentralizacji, czyli procesem skupiania uprawnień decyzyjnych w organach wysoko umiejscowionych w strukturze administracji publicznej, czy też z procesem przekazywania uprawnień na organy zajmujące stosunkowo niską pozycję w tej strukturze. Ujęcie statyczne polega natomiast na określeniu w wybranym momencie, czy układ uprawnień decyzyjnych można uznać przy zastosowaniu przyjętych kryteriów za centralizację lub decentralizację ${ }^{12}$.

Na gruncie niniejszego opracowania pojęcie centralizacji oznaczać będzie skupienie w drodze aktu prawnego prawa do podejmowania decyzji w ręku organów administracji zajmujących wysoką pozycję $\mathrm{w}$ ich strukturze. W przypadku samorządu terytorialnego będzie to oznaczało skupienie uprawnień do podejmowania rozstrzygnięć w ręku organu stanowiącego lub też wykonawczego danej jednostki samorządu terytorialnego, ponieważ organy te zajmują w ramach najwyższą pozycję.

Podobnie jak w przypadku dekoncentracji, także i w kontekście omawianej pary pojęć akcentuje się istotne ich elementy. W literaturze prawa administracyjnego wskazuje się, że istotnymi elementami prawnymi współczesnej centralizacji są: ścisłe wyodrębnienie prawne zadań i kompetencji na każdym stopniu organizacyjnym administra-

${ }_{11}$ J. Boć [w:] Administracja..., red. A. Boć, s. 178-179.
${ }_{12}$ J. Boć [w:] Administracja..., red. A. Boć, s. 180-181. 
cji; możliwość dekoncentrowania zadań i kompetencji na organy niższego stopnia oraz zachowanie hierarchicznego podporządkowania $\mathrm{w}$ sferze realizacji posiadanych kompetencji ${ }^{13}$.

Z kolei pojęcie decentralizacji oznacza przekazanie uprawnień należących do organów administracji zajmujących wysoką pozycję w strukturze organów państwa organom zajmującym niższą pozycję w drodze aktu prawnego. Organy, które przejmują uprawnienia, posiadają prawem zagwarantowaną względną samodzielność i niezależność w realizacji przekazanych uprawnień.

W ramach tak ujmowanej decentralizacji istotnym jej elementem jest fakt, że przekazanie uprawnień następuje w drodze aktu prawnego, najczęściej w formie ustawy. Sytuacja taka odnosi się w szczególności do struktur administracji rządowej, jak również wówczas, gdy jakieś zadania przekazywane są do realizacji samorządowi terytorialnemu. Obok formy ustawowej przekazanie uprawnień może nastąpić poprzez wykorzystanie uchwały organu stanowiącego i kontrolnego danej jednostki samorządu terytorialnego. W tym przypadku spotykamy się z aktem podmiotu zewnętrznego w stosunku do podmiotów, których proces przekazywania uprawnień dotyczy. Przykładem tego typu rozwiązań będzie przekazanie $\mathrm{w}$ drodze uchwały organu stanowiącego i kontrolnego uprawnień decyzyjnych przynależnych wójtowi, burmistrzowi czy prezydentowi na rzecz organu wykonawczego jednostki pomocniczej w gminie czy kierownikowi gminnej jednostki organizacyjnej. Rozwiązanie takie przewiduje przykładowo art. 39 ust. 4 u.s.g.

Kolejnym istotnym elementem decentralizacji wyodrębnianym w literaturze jest niezależność organu przejmującego kompetencje od organu przekazującego. Sygnalizowana tu niezależność organu przejmującego kompetencje od organu przekazującego nie może być ujmowana w sposób bezwzględny, ponieważ spotykamy się z sytuacjami, kiedy między podmiotem przekazującym i przejmującym występują różnego typu relacje, w tym także i takie, kiedy podmiot przekazujący dysponuje daleko idącymi uprawnieniami wobec podmiotu, któremu kompeten-

${ }^{13}$ Prawo administracyjne, red. J. Boć, Wrocław 2010, s. 214. 
cje są przekazywane. Przykładem takiej sytuacji są uprawnienia nadzorcze przysługujące wojewodzie względem organów jednostek samorządu terytorialnego czy wówczas, gdy decentralizacja nastąpi w drodze uchwały organu stanowiącego danej jednostki samorządu terytorialnego, ponieważ w zakresie przekazanych zadań organ wykonawczy takiej jednostki nie będzie mógł w formach prawem przewidzianych narzucić sposobu realizacji powierzonego zadania. Istotnym elementem decentralizacji jest samodzielność organu (podmiotu) w wykonywaniu przekazanych mu kompetencji ${ }^{14}$. Ten element decentralizacji oznacza, iż organ przekazujący nie może narzucać organowi (podmiotowi) przejmującemu sposobu rozwiązywania przekazanego zadania. Odstępstwa od tej zasady mogą wynikać jedynie z treści przepisu szczególnego. W szczególności uwypukli się ona wówczas, gdy organ przekazujący kompetencje będzie zarazem pełnił funkcję organu wyższego stopnia w postępowaniu administracyjnym $\mathrm{i}$ wówczas $\mathrm{z}$ racji tej funkcji będzie dysponował uprawnieniami pozwalającymi mu na ingerencję w działania podejmowane przez organ pierwszej instancji.

Ostatnim elementem decentralizacji jest niezależność przekazania kompetencji od woli organu dotychczas posiadającego kompetencje oraz od woli organu przejmującego je do realizacji. Element ten wynika z tego, że podmiotem podejmującym akt, na mocy którego nastąpi przeniesienie uprawnień, jest podmiot zewnętrzny w stosunku do zainteresowanych. Oznacza to, że podmiot przekazujący i podmiot przejmujący nie mają wyboru, lecz muszą się zgodzić z postanowieniami stosownego aktu przenoszącego te uprawnienia ${ }^{15}$.

\section{4.}

Przedstawiona powyżej analiza teoretycznych aspektów pojęć będących przedmiotem zainteresowania stwarza dobrą podstawę dla rozważenia charakteru rozwiązań przyjętych przez ustawodawcę w przywołanych na wstępnie unormowaniach prawnych.

\footnotetext{
${ }^{14}$ J. Boć [w:] Administracja..., red. A. Boć, s. 186.

15 J. Zimmermann, Prawo..., s. 178.
} 
W pierwszej kolejności przyjdzie dostrzec, że ustawodawca stworzył jednostkom samorządu terytorialnego możliwość zapewnienia wspólnej obsługi wymienionym w ustawie podmiotom funkcjonującym w poszczególnych jednostkach. Oznacza to, że jest to jedna z możliwych do wykorzystania przez daną jednostkę samorządu terytorialnego form organizacyjnych. Jednostka samorządu terytorialnego może z niej skorzystać, ale nie ma takiego obowiązku. Do rozważenia pozostaje inne zagadnienie, a mianowicie zakres, w jakim można z tej możliwości skorzystać, czy musi to być ujęcie całościowe, czyli odtwarzające rozwiązanie przyjęte przez ustawodawcę, czy też może to być rozwiązanie częściowe, dostosowane do sytuacji występującej w danej jednostce. W mojej ocenie opowiedzieć należy się za drugą z wyodrębnionych możliwości, ponieważ ustawodawca nie wprowadza rozwiązań o charakterze zero-jedynkowym i daje w tym zakresie duże pole samodzielnego działania przez uprawnione do tego organy danej jednostki samorządu terytorialnego. Na marginesie można zaznaczyć, że utworzenie wspólnej obsługi nie musi być wyrazem woli danej jednostki samorządu terytorialnego, lecz może być efektem działań podmiotów utworzonych przez daną jednostkę i być wyrazem ich aktywności i kreatywności w zakresie sposobu realizacji postawionych przed nimi zadań.

Wspólna obsługa może być prowadzona przez jednostkę obsługującą, którą może być aparat pomocniczy organu wykonawczego danej jednostki samorządu terytorialnego (urząd gminy, urząd miejski, starostwo czy urząd marszałkowski), może to być powołana w tym celu jednostka organizacyjna (gminy, powiatu czy województwa), może to być jednostka organizacyjna związku komunalnego (międzygminnego, gminno-powiatowego czy też powiatowego) przewidzianego przepisami prawa. Wybór formy organizacyjnej jednostki obsługującej zależny jest od tego, czy jednostkami obsługiwanymi są jednostki organizacyjne zaliczane do sektora finansów publicznych, czy też są instytucjami kultury bądź innym zaliczonym do sektora finansów publicznych osobami prawnymi utworzonymi na podstawie odrębnych ustaw w celu wykonywania zadań publicznych. Do tej kategorii podmiotów nie mogą być zaliczane przedsiębiorstwa, instytuty badawcze, banki i spółki prawa 
handlowego. Wprowadzone przez ustawodawcę rozróżnienie pozornie jest czytelne, ponieważ do pierwszej grupy zaliczone zostały wyłącznie jednostki organizacyjne kreowane na podstawie ustrojowych ustaw samorządowych, a zatem na mocy u.s.g., u.s.p. i u.s.w. Z kolei do drugiej grupy przypisano jednostki organizacyjne będące instytucjami kultury oraz inne zaliczone do sektora finansów publicznych gminne, powiatowe czy wojewódzkie osoby prawne utworzone na podstawie odrębnych ustaw w celu wykonywania zadań publicznych. Równocześnie w odniesieniu do tej kategorii wprowadzono kryterium negatywne, a mianowicie wymieniono szereg podmiotów, które zostały wyłączone z możliwości objęcia wspólną obsługą. Wyłączenie to ma charakter zamknięty, a zatem obejmuje jedynie rodzaje podmiotów wymienionych w stosownych regulacjach ustrojowych i obejmuje, jak zostało zaznaczone: przedsiębiorstwa, banki, instytuty badawcze i spółki prawa handlowego. Zauważyć należy, że pojęcie jednostek sektora finansów publicznych ma swoje unormowanie w art. 9 ustawy z 27.08.2009 r. o finansach publicznych ${ }^{16} \mathrm{i}$ w ramach niniejszego opracowania nie będzie bliżej analizowane. Na marginesie można jedynie zaznaczyć, że dyferencjacja wyodrębnionych grup podmiotów będzie się sprowadzała do tego, że w pierwszej z nich będą wyłącznie jednostki organizacyjne tworzone na mocy samorządowych ustaw ustrojowych, natomiast do drugiej będą przynależały wszystkie inne, zwłaszcza powoływane na mocy przepisów zamieszczonych w przepisach prawa materialnego.

Przedstawione powyżej rozróżnienie ma istotne znaczenie, ponieważ ustanowienie wspólnej obsługi będzie się odbywało w oparciu o odmienne zasady. W przypadku pierwszej z wyodrębnionych grup podmiotów ustawodawca przewidział niezbędność działań podejmowanych przez organ stanowiąco-kontrolny danej jednostki samorządu terytorialnego, natomiast $\mathrm{w}$ przypadku drugiej $\mathrm{z}$ wyodrębnionych grup przewidziano inną formę prawną, a mianowicie porozumienia zainteresowanych podmiotów.

${ }^{16}$ Dz.U. z 2017 r. poz. 2077 ze zm. 


\section{5.}

Pierwszą z wyodrębnionych możliwości są działania podejmowane przez podmiot, który w danej jednostce samorządu terytorialnego bądź też związku komunalnego będzie podejmował rozstrzygnięcie. Przepisy prawa przewidują, że podmiotem decydującym o wskazanym wyborze jest organ stanowiąco-kontrolny (gminy, powiatu czy województwa bądź też odpowiedniego związku komunalnego). Skorzystanie z przysługującej możliwości nastąpi w drodze uchwały przyjmowanej przez odpowiednio radę gminy, radę miejską, radę powiatu czy sejmik województwa, jak również odpowiednie zgromadzenie związku komunalnego. Uchwała taka jako akt kreujący nowy podmiot $\mathrm{w}$ danej jednostce lub też dokonujący zmian w zakresie funkcjonowania już istniejących podmiotów będzie miała status aktu prawa miejscowego. Z tego też powodu dla jej obowiązywalności będzie wymagane opublikowanie w wojewódzkim dzienniku urzędowym. Na marginesie można zauważyć, że w danej jednostce samorządu terytorialnego może być powołanych kilka jednostek obsługujących i pozostawione zostało to uznaniu organu uprawnionego do podejmowania w tym zakresie rozstrzygnięć. Liczba tego typu jednostek uzależniona będzie od potrzeb występujących w danej jednostce samorządu terytorialnego. Można założyć, że im większa (liczebniejsza) jednostka samorządu terytorialnego, tym tego typu podmiotów będzie więcej. Podkreślić należy, że jedynie organ stanowiąco-kontrolny będzie uprawniony do podejmowania rozstrzygnięć, tym samym powierzenie tych zadań aparatowi pomocniczemu organu wykonawczego danej jednostki samorządu terytorialnego bądź wskazanej jednostce organizacyjnej już funkcjonującej, względnie utworzenie jednostki obsługującej, jak również wybranie jednostek obsługiwanych jest niezależne od woli obu grup podmiotów. Działania te podejmowane są bez brania pod uwagę woli zainteresowanych jednostek. Stwierdzenie to odnosi się do aspektów formalnych, ponieważ w praktyce może to wyglądać odmiennie, zwłaszcza w przypadku podmiotów już istniejących i dysponujących formalną samodzielnością, gdyż w ich przypadku możliwe będą działania zmierzające do wspólnego określenia zakresu podmiotowego i przedmiotowego wspólnej obsługi. 
Organ stanowiąco-kontrolny (zgromadzenie związku komunalnego), przyjmując przedmiotową uchwałę, obowiązany jest zamieścić w niej minimum trzy elementy, a mianowicie:

1) wskazać, kto jest jednostką obsługującą;

2) wymienić jednostki obsługiwane oraz

3) wyznaczyć zakres obowiązków powierzonych jednostkom obsługującym.

Brak któregoś z wymienionych elementów będzie skutkował wadliwością uchwały uzasadniającą eliminację jej z obrotu prawnego. Oznacza to, że ustawodawca wyznaczył minimalne wymogi stawiane tej uchwale, natomiast nie określił wszystkich jej elementów, ponieważ organ ją przyjmujący będzie mógł w niej zamieścić także inne postanowienia, stosownie do potrzeb występujących lokalnie. Określenie w przedmiotowej uchwale jednostek obsługujących będzie się sprowadzało do wymienienia tych jednostek. W analogiczny sposób widzieć należy określenie jednostek obsługiwanych, przy czym w tym przypadku, jak się wydaje, niezbędne będzie przypisanie ich do wcześniej wymienionych jednostek obsługujących. Odmiennie widzieć należy kwestię związaną z zakresem obowiązków powierzonych jednostkom obsługującym, ponieważ w tym zakresie decyzja będzie przynależała do podmiotu przyjmującego wskazaną uchwałę. Na marginesie przyjdzie zauważyć, że ustawodawca już w przepisach rangi ustawowej przewidział pewne uprawnienia po stronie jednostki obsługującej oraz przydał pewne prawa jednostkom obsługiwanym. Jednostka obsługująca ma prawo żądania od jednostek obsługiwanych informacji oraz wglądu w dokumentację w zakresie niezbędnym do wykonywania zadań w ramach wspólnej obsługi. Na wstępie przyjdzie zauważyć, że ustawodawca z jednej strony przydał przedstawione powyżej jednostce obsługującej prawo, jednakże w regulacji tej brak jest rozwiązań pozwalających w sposób skuteczny realizować to prawo. Jest ona dostosowana do sytuacji, kiedy między jednostką obsługującą a jednostką obsługiwaną nie występują żadne konflikty czy nieporozumienia, natomiast brak jest rozwiązań normujących sytuację w przypadku zaistnienia sytuacji spornych między wskazanymi jednostkami. W tej sytuacji można postulować, aby przyjmowana przez organ stanowiąco-kon- 
trolny (zgromadzenie związku) uchwała normująca to zagadnienie zawierała regulacje w tym zakresie.

Kwestią wymagającą rozważenia jest charakter prawny przedmiotowej uchwały. Mając na uwadze, że jej mocą następuje bądź powołanie nowej jednostki organizacyjnej, bądź też przeniesienie szeregu obowiązków z jednego podmiotu na drugi, to opowiedzieć przyjdzie się za stanowiskiem, że w tym przypadku podejmowana jest uchwała mająca status aktu prawa miejscowego ${ }^{17}$. Zatem uchwała taka dla swojej ważności będzie musiała być opublikowana w wojewódzkim dzienniku urzędowym.

Przedmiotowa uchwała będzie podlegała czynnościom nadzorczym ze strony wojewody, który będzie zobowiązany do ich podjęcia w przypadku dostrzeżenia w niej uchybień o istotnym charakterze. Za takie uchybienia uznać będzie należało pominięcie któregoś z obligatoryjnych elementów tej uchwały, względnie zamieszczenie w niej takich rozwiązań, które będą pozostawały w sprzeczności z regulacjami o charakterze ustawowym.

6.

Drugą z wyróżnionych możliwości jest porozumienie instytucji obsługiwanej z instytucją obsługującą po uprzednim poinformowaniu o zamiarze wprowadzenia takiego rozwiązania organu wykonawczego danej jednostki samorządu terytorialnego. W świetle powyższego ustalenie wspólnej obsługi w przypadku tej grupy podmiotów zależne jest od ich stanowiska. Obowiązek poinformowania organu wykonawczego jednostki samorządu terytorialnego ma tu charakter subsydiarny i nie wpływa na skuteczność działań podejmowanych przez zainteresowane podmioty. Zauważyć należy, że ustawodawca nie wyposażył organu wykonawczego w żaden formalny instrument umożliwiający wypowiedzenie się w tym zakresie. W zasadzie organ

17 Szerzej na ten temat zob. D. Dąbek, Prawo miejscowe samorządu terytorialnego, Bydgoszcz-Kraków 2003, s. 181. 
taki może wykorzystywać jedynie innego typu możliwości oddziaływania na działania podejmowane przez zainteresowane podmioty. W konsekwencji uznać należy, że wprowadzone przez ustawodawcę rozwiązanie ma charakter pozorny i nie przyczynia się do usprawnienia tego procesu, jak również do podniesienia jakości podejmowanych działań.

Kolejną kwestią, którą należy tu rozważyć, jest forma prawna ustanowienia wspólnej obsługi. Ustawodawca wskazuje, że wymagane jest tu porozumienie między jednostką obsługiwaną i jednostką obsługującą. Na gruncie prawa samorządowego porozumienie ma swoją treść, znaczenie i charakter ${ }^{18}$, jednakże przyjdzie stwierdzić, że w tym przypadku nie można mówić o porozumieniu komunalnym przewidzianym przepisami ustaw samorządowych. W omawianym zakresie pojęcie porozumienia ujmowane powinno być jako forma umowy między dwoma zainteresowanymi podmiotami ${ }^{19}$. Porozumienie takie będzie wymagało formy pisemnej i w jego treści powinny być zamieszczone regulacje dotyczące zakresu wspólnej obsługi. Wskazane porozumienie $\mathrm{z}$ uwagi na charakter podmiotów, które będą go zawierały, jak również mając na uwadze zakres ich zadań i przysługujących kompetencji, nie będzie miało statusu prawa miejscowego i nie będzie występował wymóg jego publikacji. W zasadzie porozumienie to można uznać za akt wewnętrzny dwóch zainteresowanych jednostek. Na marginesie można zauważyć, że jednostka obsługująca może podpisać stosowne porozumienia z większą liczbą podmiotów obsługiwanych. W tym zakresie relacje będą występowały jedynie między zainteresowanymi podmiotami, czyli między jednostką obsługującą i jednostką obsługiwaną, natomiast między jednostkami obsługiwanymi nie będzie występowała żadna relacja formalnoprawna. Stwierdzenie takie będzie prawdziwe także wówczas, gdy jednostka obsługująca będzie warunkowała wykonywanie

${ }^{18} \mathrm{Na}$ temat porozumienia komunalnego zob. K. Bandarzewski [w:] Komentarz do ustawy o samorzadzie gminnym, red. P. Chmielnicki, Warszawa 2004, s. 488-492.

19 Porozumienie to będzie miało zbliżony charakter do porozumień zawieranych na mocy art. 191 ust. 3 ustawy o wspieraniu rodzin i systemie pieczy zastępczej; zob. S. Nitecki, A. Wilk, Ustawa o wspieraniu rodzin i systemie pieczy zastępczej. Komentarz, Warszawa 2016, s. 852-853. 
obsługi od zgłoszenia się do niej innych podmiotów, ponieważ pomiędzy jednostkami obsługiwanymi w dalszym ciągu brak będzie formalnoprawnych relacji.

7.

Zagadnieniem wymagającym prezentacji jest zakres przedmiotowy wspólnej obsługi. Ustrojowe ustawy samorządowe wskazują, że obsługa ta ma objąć w szczególności problematykę administracyjną, finansową i organizacyjną. W tym przypadku dostrzec należy, że wyliczenie to nie ma charakteru wyczerpującego, ponieważ ustawodawca posłużył się w nim zwrotem „w szczególności”. Regulacja taka oznacza, że prawodawca lokalny może rozszerzyć zakres spraw, które będą wspólnie obsługiwane. Na marginesie można jedynie zaznaczyć, że występujące w ustawach ustrojowych określenia „administracyjna, finansowa czy organizacyjna" $z$ jednej strony są czytelne i pozwalają na wyznaczenie ram przedmiotowych wspólnej obsługi, jednakże przyjdzie dostrzec, że wszystkie te pojęcia nie posiadają wyznaczonego w sposób precyzyjny zakresu, a zatem mogą w praktyce rodzić się wątpliwości interpretacyjne. Mając na uwadze sygnalizowaną okoliczność przyjdzie postulować, aby uchwała organu stanowiąco-kontrolnego (zgromadzenia związku) czy porozumienie zawarte przez jednostkę obsługiwaną z jednostką obsługującą w sposób precyzyjny wyznaczały zakres wspólnej obsługi. W zasadzie jest to jedyne miejsce, w którym zakres przedmiotowy wspólnej obsługi może zostać doprecyzowany. Rozpatrując problematykę zakresu przedmiotowego wspólnej obsługi, w polu widzenia muszą znajdować się elementy o charakterze wyłączającym objęcie wspólną obsługą, jak również rozwiązania wprowadzające mechanizmy nakazujące przekazanie całości posiadanych kompetencji. Podkreślić trzeba, że zakres wspólnej obsługi nie może obejmować kompetencji kierowników jednostek zaliczanych do sektora finansów publicznych do dysponowania środkami publicznymi oraz zaciągania zobowiązań. Ponadto zakresem wspólnej obsługi nie może być objęte sporządzanie i zatwierdzanie planu finansowego oraz przenoszenie wydatków w tym planie. Rozwiązanie takie uznać należy za zasadne, ponieważ jednostka ob- 
sługująca nie może decydować za jednostkę obsługiwaną o jej środkach finansowych i sposobie ich wykorzystania. Zauważyć należy, że jednostka obsługująca w przypadku powierzenia jej obowiązków z zakresu rachunkowości i sprawozdawczości przejmuje je w całości, a zatem nie jest dopuszczalna sytuacja, że przejmuje jedynie część tych zadań. Z tytułu wykonywania powierzonych zadań jednostka obsługująca jest uprawniona do przetwarzania danych osobowych w zakresie i w celu niezbędnym do wykonywania zadań w zakresie wspólnej obsługi.

\section{8.}

W podsumowaniu niniejszych rozważań przyjdzie uznać, że ustawodawca w zakresie zapewnienia wspólnej obsługi wykorzystał dwie różne teoretyczne możliwości, przy czym żadna z nich nie została wykorzystana w sposób czysty z przyjmowanym w literaturze wzorcem. Powierzenie wspólnej obsługi mocą uchwały organu stanowiąco-kontrolnego danej jednostki samorządu terytorialnego wyczerpuje szereg elementów charakterystycznych dla centralizacji. W pierwszej kolejności dostrzec należy, że skupienie uprawnień w gestii jednego podmiotu następuje mocą aktu o charakterze normatywnym (aktu prawa miejscowego). Następstwem przyjętej uchwały jest skupienie uprawnień w ręku jednego podmiotu zajmującego, nadto dzieje się to mocą aktu organu, który względem podmiotów objętych przekazaniem i przejęciem zadań zajmuje pozycję zwierzchnią, a zatem podmioty uczestniczące w tej czynności nie mają wpływu na jej podejmowanie. Odstępstwem od istotnych elementów centralizacji jest to, że podmiot sprawujący obsługę nie zajmuje wysokiej pozycji w strukturze organów danej jednostki samorządu terytorialnego. Utworzenie wspólnej obsługi w drodze uchwały organu stanowiącego i kontrolnego (zgromadzenia związku komunalnego) skutkuje tym, że procesu tego nie można określić mianem koncentracji, ponieważ działanie to nie jest podejmowane w następstwie woli podmiotów uczestniczących w nim, a zatem brak jest jednego $\mathrm{z}$ fundamentalnych elementów wyodrębnianych w ramach koncentracji. Wykorzystanie drugiej z wyodrębnionych form kreowania wspólnej obsługi, a mianowicie porozumie- 
nia między jednostką obsługującą a jednostką obsługiwaną, odbiega w istotny sposób od obu par pojęć wyodrębnionych powyżej. Zatem nie może być ono rozpatrywane w kontekście centralizacji czy koncentracji, lecz musi być widziane jako prawna forma działania przysługująca wskazanym podmiotom i przez nie wykorzystana. Z uwagi na nietrwały charakter porozumienia, ponieważ zakłada ono wspólną wolę obu zainteresowanych podmiotów w jego zawarciu, to dostrzegając występowanie istotnych odmienności w stosunku do modelu koncentracji, proces ten można rozpatrywać jako koncentrację uprawnień w ręku podmiotu obsługującego. W konsekwencji uznać należy, że ustawodawca przedstawionymi regulacjami wprowadził do porządku prawnego możliwość wspólnej obsługi przy wykorzystaniu odmiennych teoretycznoprawnych rozwiązań.

\section{Bibliografia:}

Administracja publiczna, red. J. Boć, Wrocław 2003

Buckley R., Maurer R., Decentralizacja w Polsce: tworzenie potencjału racjonalnego zarządzania i integracji $z$ Uniq Europejską, ST 2000/7-8

Dąbek D., Prawo miejscowe samorządu terytorialnego, Bydgoszcz-Kraków 2003

Komentarz do ustawy o samorzadzie gminnym, red. P. Chmielnicki, Warszawa 2004

Lang J., Służewski J., Wierzbowski M., Wiktorowska A., Polskie prawo administracyjne, Warszawa 1995

Leksykon administratywisty, red. S. Wrzosek, A. Haładyj, M. Domagała, Radom 2013

Lipowicz I., Samodzielność samorządu terytorialnego w świetle konstytucji, „Przegląd Sejmowy” 2007/4

Nitecki S., Prawo do pomocy społecznej w polskim systemie prawnym, Warszawa 2008

Nitecki S., Wilk A., Ustawa o wspieraniu rodzin i systemie pieczy zastępczej. Komentarz, Warszawa 2016

Prawo administracyjne, red. J. Boć, Wrocław 2010

Ura E., Prawo administracyjne, Warszawa 1999

Zimmermann J., Prawo administracyjne, Warszawa 2014 